\title{
Identification and quantification of benchmarks of milk production systems in Minas Gerais ${ }^{1}$
}

\section{Matozalém Camilo Neto ${ }^{2}$, José Maurício de Souza Campos ${ }^{3}$, André Soares de Oliveira ${ }^{4}$, Sebastião Teixeira Gomes ${ }^{5}$}

\author{
${ }^{1}$ Fonte de financiamento: Apoio SEBRAE-MG. \\ 2 Consultor do Programa Educampo/SEBRAE, Minas Gerais. \\ ${ }^{3}$ Universidade Federal Rural de Pernambuco, Unidade Acadêmica de Garanhuns. Researcher from CNPq. \\ ${ }^{4}$ Instituto de Ciências Agrárias e Ambientais, UFMT, Campus Sinop. Researcher from INCT/Ciência Animal/CNPq. \\ ${ }^{5}$ Departamento de Economia Rural/UFV, Viçosa-MG.
}

\begin{abstract}
The objective of this study was to identify and quantify benchmarks of milk production systems. The technological profile and size, livestock and economic indicators of sixteen farms in the region of Triângulo Mineiro were analyzed. Indicators correlated with rate of return on capital (RRC) were identified and quantified in four scenarios of RRC $(6,8,10$ and $12 \%$ per year). The correlated indicators and their respective values in the four scenarios were: land ( $99,90,81$ and $73 \mathrm{ha})$; relation of total cows in lactation $(74,77,79$ and $82 \%)$; lactating cows per area $(0.89 ; 0.99 ; 1.11$ and 1.22 cows/ha); milk production per lactating cow $(12.04 ; 13.00 ; 13.96$ and 14.92 liters/cow/day); milk production per total cows $(9.19 ; 10.23$; 11.27 and 12.31 liters/cow/day); labor productivity (322, 349, 375 and 402 liters/day/man); land productivity (4351, 5236, 6120 and 7004 liters/ha/year); participation of total effective operational cost of activity in the gross revenue of the activity $(69,66,63$ and $60 \%)$; participation of total operational cost of activity in the gross revenue of the activity $(80,76,72$ and $69 \%)$; participation of total cost of activity in the gross revenue of the activity (93, 88, 82 and $77 \%$ ); labor cost in relation to milk gross revenue $(15,13,11$ and $9 \%)$; profitability $(15,19,23$ and 28\%); and capital investment in the activity in relation to daily milk production $(922,829,736$ and $644 \mathrm{R} \$$ /liter-day). The productivity of the factors land and animals present more correlation with profitability than labor productivity, regardless of the production size.
\end{abstract}

Key Words: administration, benchmark, production cost, profitability

\section{Introduction}

In an environment of high competition, uncertainties and gain margin reduction in which the milk producers are inserted, the effectiveness in decision-making assumes a fundamental role to the sustainability of the activity.

Sustainability can be understood as the ability of long term survival (Oliveira \& Pereira, 2009). From this point of view, the role of economic management is to assist the organization in searching and maintaining the profitability index attractive enough to ensure long term business (Oliveira \& Pereira, 2009). Thus, the identification and quantification of the profitability modulating factors is necessary.

Among the planning methods, the identification and analysis of benchmarks stand out by their security and accuracy, since the values are directly obtained from production units present in the same economic environment (Oliveira et al., 2007). In this sense, studies have been done proposing to identify the main livestock and economic indicators that influence profitability of milk production systems in Brazil (Krug, 2001; Gomes, 2005; Oliveira et al., 2007).

However, the dynamic character inherent in the production environment, the high socioeconomic, cultural, soil and climate diversity that characterize the production systems, associated with the fact that the dairy livestock is present in more than $80 \%$ of the cities of Brazil, imposes the necessity of studies by region (Oliveira et al., 2007).

Thus, the objective was to identify and quantify milk production system benchmarks in Triângulo Mineiro, which is the largest milk-producing region of Brazil (IBGE, 2011).

\section{Material and Methods}

To identify and quantify the benchmarks, sixteen milk producers were surveyed, located in the region of Triângulo Mineiro, participants of the Educampo/ Sebrae project. Data were originated from monthly records, collected between January and December 2006, whose monetary values were adjusted to January 2007 
by IGP-DI (Índice geral de preços de disponibilidade interna) (FGVDADOS, 2011).

The surveys were based on the neoclassic production theory, in which the companies pursue profit maximization or cost minimization through great combination of production factors and agricultural inputs, which are bound to certain technological patterns (Ferguson, 1996). The technological patterns, on the other hand, were preordained by the selection of benchmarks.

The technological profile, size indicators, livestock indicators and economic indicators of the companies were analyzed in this study according to Oliveira et al. (2007). The correlated coefficients of the size, livestock and economic indicators with the rate of return on invested capital were determined with the objective to identify those that affect the economic performance of the companies, according to Oliveira et al. (2007). The correlation procedure adopted was of Pearson, applying the "t" test with $10 \%$ probability level.

After the identification of the indicators that have correlation $(\mathrm{P}<0.10)$, regression equations were generated to each indicator according to the rate of return on invested capital, to quantify the benchmarks (Oliveira et al., 2007). The values of each indicator were estimated considering four scenarios of real rate of return on invested capital: 6 , 8,10 and $12 \%$ a year.

\section{Results and Discussion}

The production systems analyzed were characterized for presenting crossbred herds with predominance of Holstein, Gyr and Nellore breeds. The predominant genotypic is composed of $75 \%$ of Holstein and $25 \%$ of Gyr. Despite the predominance of the Holstein breed and the use of milking machine in most of the farms $(81 \%)$, most of the producers use the calve to stimulate the milk letdown $(75 \%)$ and do the milking with the calve standing (Table 1). This is mainly because the region is traditionally of beef cattle, where there is an old culture thought that in order to produce milk, the cow needs the presence of the calve; the absence of the calve in this moment causes reduction in the period of lactation. Without the presence of the calve, the milking is more agile and the system of rearing calves outside the milking environment is also more efficient by the livestock and economic point of view. According to Ruas et al. (2006), the presence of the calve at the time of milking does not influence the service, return to the heat and the heat demonstration rates and pregnancy until the 120 days postpartum on crossbred Dutch Zebu cows with varied blood rate.
The high use of the milking with the presence of calves, in this case, is not an indicative of low technological level. It may be explained by the valorization of the calves that are used in beef cattle raising due to the large area availability and by the presence of industries in the region. Therefore, because there is no buyer of newborn calves and because of the not very high productivity of the herd, none of these farms donate or sell calves right after the birth. The calves are representative of the composition of the property income at the end of the year. This practically prevents these animals from being eliminated at birth.

The production systems are not characterized by familiar systems; only $19 \%$ use familiar labor. Most of the properties $(81 \%)$ do not use hired labor to perform the work (Table 1). This shows the important role of the activity in the region on the generation of employment and income to the cities. According to the Dairy Livestock Survey of 2005 in Minas Gerais, on average, $44 \%$ of dairy properties use familiar labor, on the production stratum of 500 to 1000 liters of milk a day, $34 \%$ of used labor was familiar.

The systems analyzed were intensive in the use of technologies. All of them conduct two daily milking sessions and most (81\%) use artificial insemination (AI), higher than the $12.9 \%$ found in the dairy livestock survey in 2005. Most of them (81\%) use concentrate as an important input of production during the rainy period and the whole in the dry season (May to October) (Table 1).

Table 1 - Technological profile of the milk producers participants of the Educampo Project in Minas Gerais State, Brazil

\begin{tabular}{lc}
\hline Specification & $\begin{array}{c}\text { Frequency of } \\
\text { use (\%) }\end{array}$ \\
\hline Participation of family labor & 19 \\
Two daily milking sessions & 100 \\
Milking with the presence of the steer & 75 \\
Artificial insemination & 81 \\
Provision of concentrate in the dry season (April to September) & 100 \\
Provision of concentrate all year round & 81 \\
Preparation of concentrate on the farm & 62 \\
Provision of roughage in the trough in the dry season & 100 \\
Silage as roughage in the dry season & 38 \\
Sugar cane as roughage in the dry season & 62 \\
Pasture as roughage in the dry season & 100 \\
Grazing system - intermittent stocking & 69 \\
Pasture fertilization & 38 \\
Pasture irrigation & 0 \\
Milk control & 100 \\
Reproductive control & 100 \\
Financial control & 100 \\
Mechanized milking & 81 \\
Rearing of dairy females & 100 \\
Use of BST (somatotropin) & 31 \\
AIFT (artificial insemination at fixed time) & 25 \\
Embryo transfer and IVF (in vitro fertilization) & 6 \\
Age at first calving (months) & 35 \\
\hline
\end{tabular}


A remarkable feature of the region is the use of pasture to feed the cows in the rainy season (November to April). In this case, $100 \%$ of the properties analyzed use pasture as the only source of roughage in the summer (Table 1). The use of pasture as the only source of provision of forage to the animals in the rainy season constitutes one of the main advantages of economic competitiveness of these production systems studied (Silva et al., 2008).

For the dry season, $62 \%$ of the companies use corrected sugar cane as source of hay and 38\% use silage (corn and sorghum). No farm uses pasture irrigation (Table 1).

This feeding system seems to be compatible with the herd of the region that presented an average daily milk production of $11.17 \mathrm{~L} / \mathrm{cow}$ in lactation (Table 3). Animals with this production potential are very well-served nutritionally with the feed mentioned above and have a great possibility of providing a good benefit-cost ratio. According to Magalhães et al. (2006), the replacement of corn silage by sugar cane in complete diets containing $40 \%$ of concentrate to cows in lactation with average daily production of $24 \mathrm{~kg}$ of milk did not compromise the use of nutrients and the stability of the rumen. In the same study, the authors concluded that the replacement of up to $33 \%$ of corn silage by the sugar cane was technically and economically viable.

Another sign of the good technological level of these companies studied is that $100 \%$ of them do a monthly milk control, complete reproductive control and financial control. Moreover, $69 \%$ use grazing system with intermittent stocking (Table 1). Few farms (38\%) do pasture fertilization. This is possibly due to the high availability of area in the region. With the entry of other activities in this region, especially sugar cane, probably more properties will intensify the use of area through the use of fertilizer on pastures. Other technologies considered more sophisticated, with the use of BST (bovine somatotropin), AIFT (artificial insemination at fixed time) and ET/IVF (embryo transfer and in vitro fertilization) are already being used respectively in 31\%, $25 \%$ and $6 \%$ of the analyzed properties (Table 1 ). Another feature of the region is that $100 \%$ of the properties raise females for future replacement of the dams.
The daily milk production average was 803.34 liters, with variation between 259 liters to 2,168 liters/day (Table 2). This minimum production places this group of producers in the category above $200 \mathrm{~L} /$ day, which, according to the dairy livestock survey of Minas Gerais of 2005, accounts for $20 \%$ of the producers and are responsible for $68 \%$ of the milk produced in the state of Minas Gerais. Similar value was found by Fassio et al. (2006), in which farmers producing over 250 liters a day accounted for $32 \%$ of the production of the same category and $67 \%$ of the total milk produced in a sample distributed throughout the state of Minas Gerais.

The average area used for dairy livestock in these properties was 110 ha (Table 2), lower than the 130 ha, which, according to the dairy livestock survey of Minas Gerais of 2005 , was the area used by the producers to produce from 500 to 1000 liters of milk a day. As was also found in that survey, the higher price of land was located exactly in Triângulo Mineiro. With this fact, there is an evident necessity of the farms from this region to intensify the use of their areas in relation to the other regions of the state. However, this area still is very large compared with other regions, such as the state of São Paulo, where the price of the land is higher and the intensification of the area is a matter of survival in the activity.

In the region of Ituiutaba-MG, there is already a great demand for land for cultivation of sugar cane. According to data from the Livestock Department of Ituiutaba, approximately 20 to $25 \%$ of lands of the city will be occupied by this culture for production of sugar and alcohol, until 2010. These areas had been previously used mainly by livestock. The events indicate that there is need for further intensification of milk production area in this region, in order to excel these new options of activities.

The mean productivity of lactating cows was $11.17 \mathrm{~L} /$ day, with variation between 5.17 and 17.53 daily liters (Table 3). This production is compatible with the described system that uses crossbred Holstein-Zebu animals with predominance of $3 / 4$ Holstein, pasture as the main source of forage in the rainy season and sugar cane for roughage supplementation in the dry season. This mean can increase if more caution

Table 2 - Descriptive statistics of the size indicators of milk-producing companies participants of the Educampo Project in Minas Gerais State, Brazil, January to December 2006

\begin{tabular}{|c|c|c|c|c|}
\hline Specification & Average & Maximum & Minimum & Standard deviation \\
\hline Annual milk production, L/year & $293,401.88$ & $791,388.00$ & $94,729.00$ & $198,894.51$ \\
\hline Daily milk production, $\mathrm{L} /$ day & 803.84 & 2.168 .19 & 259.53 & 544.92 \\
\hline Total area, ha & 110.29 & 242.00 & 14.65 & 54.00 \\
\hline Number of cows in lactation & 71.95 & 158.04 & 24.63 & 34.71 \\
\hline Total number of cows & 100.51 & 202.96 & 27.46 & 44.65 \\
\hline Invested capital including land price, $\mathrm{R} \$$ & $762,206.72$ & $1,428,154.00$ & $126,467.00$ & $329,585.51$ \\
\hline
\end{tabular}


is given at the selection of animals and small adjustments are done in the nutritional management of the herd. These feeds have potential to produce much more when animals of greater genetic potential are used. In Minas Gerais, the production was $8.1 \mathrm{~L} /$ cow in lactation in the dairy livestock survey of 2005 , while with producers of 500 to $1000 \mathrm{~L} /$ day, the average was 10.47 liters per cow in lactation a day. Fassio et al. (2006) found $10.39 \mathrm{~L} / \mathrm{cow}$ in lactation in the overall average of a high sample of producers monitored by Emater-MG in the entire state of Minas Gerais.

The total proportion of lactating cows was $71.58 \%$, below the amount of $83 \%$, considered as ideal (Table 3 ). The percentage of cows in lactation is mathematically expressed by the ratio between the numbers of cows in lactation in relation to the total number of cows $(\% \mathrm{CL}=$ NCL/TNC) (Oliveira et al., 2007). This indicator is affected by the lactation persistence of the animals (genetic mainly) beyond the reproductive efficiency, which is directly affected by nutrition, health and general reproductive management of the herd. In Minas Gerais, in the survey of 2005 for the dairy livestock, the average was $66 \%$ in relation to the total cows. In the study conducted by Fassio et al. (2006), the average found was $56 \%$ of lactating cows per total cows for the producers of above $250 \mathrm{~L} /$ day and $55 \%$ in the overall average of the sampled in the entire state of Minas Gerais.

The percentage of lactating cows in relation to the total herd was $33.3 \%$ (Table 3 ). The ideal for this indicator is to be close to $60 \%$, with the minimum value of $40 \%$, according to the data center of the Educampo Project. The result of 33.35 is far from ideal. Besides the factors previously mentioned, this indicator is influenced by the efficiency of rearing females of the herd. The higher the age at first calving, the higher the number of unproductive animals in the system and consequently the lower the representativeness of lactating cows in relation to the total herd. In order to become more efficient and have more cows in production, there is need to improve the rearing systems of calves and heifers of these farms, which is currently very long (35 months). For the described system, the age of first calving of 30 months seems to be more compatible compared with the current 35 months. In addition to anticipating the age at calving, better fed and well-managed animals are more likely to express their genetic potential.

Two other indicators considered as factors of intensification and related to the use of land are lactating cows and milk production per hectare. The average of cows in lactation/ha was 0.65 (the ideal considered by the Educampo Project data center is at least 1 cow in lactation for each hectare used in the dairy activity). For the production by area, there is no value considered ideal, but the consensus is that the higher production per hectare balanced with the production system, the better the rate of return on invested capital. The obtained values of 0.65 cows in lactation/ha and 2,660.37 L/ha/year are considered low and reinforce the need for a further intensification in the use of the land factor (Table 3). This statement is reinforced when it is found that the land represents a lot in the total invested capital. In the dairy livestock survey of Minas Gerais of 2005, the land represented $70 \%$ of the total investment in milk production.

Fassio et al. (2006) found an average of 2,529 $\mathrm{L}$ of milk/ha/year for the producers of above of $250 \mathrm{~L} /$ day and the overall average in Minas Gerais was 1862 liters. The dairy livestock survey of Minas Gerais of 2005 showed 1,188 liters/ha/year in the overall average of the state. This low production per area certainly influenced the rate of return on capital of only $1.92 \%$ a year to the producers interviewed in the survey of 2005.

The labor productivity was 288.77 liters per man a day (Table 3). With the constant increase in the labor cost, the major efficiency of labor is always necessary. In this case, there is also no ideal value, but the more milk produced by men, the better the economic result of the activity, considering the other factors in balance. For the data center of the Educampo Project, on farms that use milking machines, this value must be superior to 450 liters, while for the manual milking, it must be about 250 liters a day. In Minas Gerais, in the dairy livestock survey of 2005, the average milk per man was $182 \mathrm{~L} /$ day, and in the stratum

Table 3 - Descriptive statistics of husbandry indicators of milk-producing companies participants of Educampo Project in Minas Gerais State, January to December 2006

\begin{tabular}{|c|c|c|c|c|}
\hline Specification & Average & Maximum & Minimum & Standard deviation \\
\hline Productivity per lactating cow, L/cow/day & 11.17 & 17.53 & 5.17 & 3.48 \\
\hline Productivity per total cows, L/cow/day & 8.00 & 15.72 & 3.60 & 3.18 \\
\hline Relation of lactating cows per total cows, $\%$ & 71.58 & 89.68 & 61.32 & 7.57 \\
\hline Relation of lactating cows per total herd, $\%$ & 33.30 & 49.21 & 20.09 & 6.52 \\
\hline Number of lactating cows per area, cows/ha & 0.65 & 1.68 & 0.37 & 0.38 \\
\hline Land productivity, L/ha/year & $2,660.37$ & $10,756.66$ & $1,039.83$ & $2,715.06$ \\
\hline Labor productivity, L/day labor & 288.77 & 562.03 & 126.16 & 128.47 \\
\hline
\end{tabular}


of producers of 500 to 1000 daily liters of milk, it was $297 \mathrm{~L} / \mathrm{man} /$ day. In the survey conducted also in Minas Gerais by Fassio et al. (2006), the values found were very close to the ones from the 2005 survey. They reported 293 and $218 \mathrm{~L} / \mathrm{man} /$ day, respectively, to the producers with above $250 \mathrm{~L} /$ day and to the overall average of the state.

The gross revenue of milk/gross revenue dairy activity was $80 \%$ (Table 4 ). It means that $20 \%$ of the dairy activity gross revenue was from animal sales and other sources of revenue. This value is compatible with the other features of the production systems of these properties, mainly in relation to the productivity of lactating cows. For the Educampo data center, a livestock and economically balanced production system shows the following relation between the productivity of lactating cows and the share of the milk income in gross revenue of a dairy business. For production lower than 8 liters per lactating cow a day, the milk gross revenue represents $60 \%$ to $70 \%$ of the dairy activity gross revenue. For production of 12.1 to 18 liters per lactating cow a day, the milk represents $80.1 \%$ to $90 \%$ of the dairy activity gross revenue; and for systems that have animals producing more than 18 liters/ day, milk represents $80.1 \%$ to $90 \%$ of the dairy activity gross revenue.

The expenditure on concentrate of these pasturebased milk production systems is usually lower than the cost on feedlot systems of Holstein cattle. In this case, the value found is compatible with the described system and is $26.9 \%$ of the gross revenue of milk, in other words, for every 100 liters of milk produced, 26.9 liters are spent with concentrate to all the animals of the herd (Table 4). According to the Educampo Project data center, the most efficient farms with these features of production spend $30 \%$ less than the milk gross revenue with concentrate to the herd.

For labor, the more economically efficient farms spend less than $15 \%$ of the milk gross revenue. The value found in this study was the average $16.72 \%$ (Table 4 ). There is need to improve the labor productivity, in order for this indicator to become appropriate with the production system features of this analyzed group.

As a management tool, it is essential that the company have the accurate knowledge of its cost of production. In this methodology analyzed, the cost is split in three different levels: the effective operational cost (EOC), important in a short-term analysis; the total operational cost (TOC), instrument of analysis in the medium term considering the depreciation of improvement and machines and finally the total cost (TC), which is an instrument of analysis in the long term. In a temporal analysis, the EOC shows us the availability of the activity in the short term, while the TOC and TC show us if the production system has sustainability in the short and medium terms (Oliveira et al., 2007). In this sense, the farms must always seek to work with positive gross margin. The negative gross margin cannot pay off the immediate expenditures for the production and, in this case, the best option, from the economic point of view, is to quit the business.

In the analysis of net margin, it was found that the companies were able to remunerate the damage (depreciations) of the production factors as improvements, machines and equipment beyond compensation or familiar labor (Table 5). This remuneration might be higher, equal to or lower than the interest of market opportunity, which might be measured through the profit.

Table 4 - Descriptive statistics of the production costs and gross revenue of milk-producing companies participants of the Educampo Project in Minas Gerais State, January to December 2006

\begin{tabular}{|c|c|c|c|c|}
\hline Specification & Average & Maximum & Minimum & Standard deviation \\
\hline Gross revenue of the dairy activity, $\mathrm{R} \$ /$ year & $202,793.00$ & $498,451.00$ & $68,757.00$ & $131,211.17$ \\
\hline Gross revenue of milk, R\$/year & $162,458.88$ & $448,580.00$ & $46,286.00$ & $114,296.35$ \\
\hline Gross revenue of milk/gross revenue dairy activity, $\%$ & 80.06 & 94.44 & 30.81 & 14.76 \\
\hline Milk price, $\mathrm{R} \$ / \mathrm{L}$ & 0.54 & 0.59 & 0.49 & 0.03 \\
\hline Annual cost with concentrate to the herd, $\mathrm{R} \$ /$ year & $46,664.69$ & $142,048.00$ & $3,745.00$ & $41,508.03$ \\
\hline Cost with hired labor of the dairy activity, R\$/year & $24,832.25$ & $67,936.00$ & 0.00 & $17,914.43$ \\
\hline Relation of cost with concentrate per milk gross revenue, $\%$ & 26.92 & 46.90 & 8.09 & 10.05 \\
\hline Relation of labor cost per milk revenue, $\%$ & 16.72 & 38.52 & 0.00 & 9.34 \\
\hline Effective operational cost of the dairy activity, $\mathrm{R} \$ /$ year & $162,097.88$ & $420,658.00$ & $40,639.00$ & $112,797.38$ \\
\hline Total operational cost of the dairy activity, $\mathrm{R} \$ /$ year & $181,792.69$ & $447,825.00$ & $53,678.00$ & $116,977.66$ \\
\hline Total cost of the dairy activity, $\mathrm{R} \$ /$ year & $210,533.06$ & $506,621.00$ & $67,716.00$ & $131,030.25$ \\
\hline Effective operational cost of milk, $\mathrm{R} \$ / \mathrm{L}$ & 0.39 & 0.49 & 0.18 & 0.08 \\
\hline Total operational cost of milk, $\mathrm{R} \$ / \mathrm{L}$ & 0.46 & 0.58 & 0.28 & 0.08 \\
\hline Total cost of milk, $\mathrm{R} \$ / \mathrm{L}$ & 0.54 & 0.72 & 0.38 & 0.10 \\
\hline Relation of milk effective operacional cost per milk price, $\%$ & 72.04 & 90.35 & 37.47 & 13.08 \\
\hline Relation of milk total operacional cost per milk price, $\%$ & 84.46 & $(108.46)$ & 56.44 & 13.63 \\
\hline Relation of milk total cost per milk price, $\%$ & $(100.24)$ & $(139.25)$ & 76.86 & 17.20 \\
\hline
\end{tabular}


As for the profit, there are three possibilities of different situations. The zero (normal) profit is a state of equilibrium, in which the business compensation is compatible with the opportunity interest established. In the case of negative profit, it shows that the compensation is lower than the opportunity interest established. And finally, in case of more than zero profit (supernormal profit), it means the business compensation is higher than the opportunity interest established (Oliveira \& Pereira, 2009). The annual values found for gross margin, net margin and profit were respectively $\mathrm{R} \$ 40,688.00, \mathrm{R} \$ 23,065.00$ and $\mathrm{R} \$ 9,155.00$ (Table 5).

The negative profit shows the necessity to improve the business compensation in order to become more competitive than the interest of $6 \%$ a year used in this study with market opportunity interest. In the long term, the business attractiveness of these farms analyzed is lower than the opportunity interest; some of them may withdraw from the production system or adapt in order to improve the economic result. In short and medium terms, the companies are well compensated, in which the monthly disbursements with agricultural inputs, depreciation and own labor compensation are being paid.

Effective operational cost, total operational cost and total cost milk represented $72.04 \%, 84.46 \%$ and $100.24 \%$ of the milk price (Table 4). According to the Educampo Project data center, the values for these three indicators must be respectively $65 \%, 75 \%$ and $85 \%$. With the values obtained, it can be verified that more milk than the recommended is being spent to pay the production cost. In the short and medium term analyses, the business is being compensated properly to pay the disbursements, depreciation and own labor. As previously mentioned, here one can also conclude that in the long term analysis the activity is not attractive from the economic point of view. Over 90 liters of milk are spent to pay the production cost of 100 liters.

The average rate of return on invested capital was $3.46 \%$ a year, lower than the real rate (nominal rate minus inflation) of opportunity interest set previously in the profit calculation (6\% a year) (Table 6$)$. This value classifies the business as of low attractiveness, due this remuneration is less than the market opportunity. With time, if an improvement in remuneration of the capital invested in these dairy livestock properties does not happen, there may be migration to other businesses.

The low remuneration obtained can be explained mostly by the high capital invested by these companies. For each liter of milk produced daily, there is $\mathrm{R} \$ 1,039.29$ invested. It is a very high value compared with the volume of milk produced per day. According to the Educampo Project data center, this value should not be over R $\$ 500.00$. With this valuable management information, the companies can take corrective actions to improve their economic performance. Livestock adjustments must be made for the economic part to be satisfactory and become more attractive when compared with other businesses.

Among the production factors, the resources cows in lactation and total cows of the herd do not present correlation $(\mathrm{P}>0.10)$ with the rate of return on invested capital (Table 7). On the other hand, the land factor showed high positive correlation $(\mathrm{P}<0.10)$ with profitability (Table 7).

Two other indicators related to the use of land (number of lactating cows per area occupied by the herd and land productivity) also had high positive correlation $(\mathrm{P}<0.10)$ with the rate of return on capital (Table 7). The land has

Table 5 - Descriptive statistics of gross margin, net margin and profit of milk-producing companies participants of Educampo Project in Minas Gerais State, Brazil, January to December 2006

\begin{tabular}{|c|c|c|c|c|}
\hline Specification & Average & Maximum & Minimum & Standard deviation \\
\hline Dairy gross margin of the activity, $\mathrm{R} \$ /$ year & $40,688.06$ & $80,011.00$ & $1,155.00$ & $26,392.06$ \\
\hline Dairy net margin of the activity, $\mathrm{R} \$ /$ year & $23,065.05$ & $59,532.00$ & $-22,952.00$ & $23,906.70$ \\
\hline Dairy profit activity, $\mathrm{R} \$$ /year & $-9,154.69$ & $23,481.00$ & $-58,047.00$ & $22,350.76$ \\
\hline Milk gross margin, $\mathrm{R} \$ / \mathrm{L}$ & 0.16 & 0.55 & 0.01 & 0.13 \\
\hline Milk net margin, $\mathrm{R} \$ / \mathrm{L}$ & 0.09 & 0.35 & -0.13 & 0.10 \\
\hline Milk profit, $\mathrm{R} \$ / \mathrm{L}$ & -0.02 & 0.15 & -0.34 & 0.12 \\
\hline Dairy activity gross margin per total cows, $\mathrm{R} \$ /$ cow/year & 401.17 & 1.168 .00 & 20.68 & 281.68 \\
\hline Dairy activity gross margin per area, $\mathrm{R} \$ /$ ha/year & 456.92 & 2.223 .00 & 14.62 & 527.32 \\
\hline
\end{tabular}

Table 6 - Descriptive statistics of profitability indicators of milk-producing companies participants of Educampo Project in Minas Gerais State, Brazil, January to December 2006

\begin{tabular}{|c|c|c|c|c|}
\hline Specification & Average & Maximum & Minimum & $\begin{array}{l}\text { Standard } \\
\text { deviation }\end{array}$ \\
\hline Rate of return of the capital invested in the activity including the land price, $\%$ a year & 3.46 & 17.60 & -2.70 & 4.61 \\
\hline Capital invested in the activity in relation to the daily milk production, $\mathrm{R} \$ / \mathrm{L}$-day & $1,039.29$ & $1,871.22$ & 292.92 & 482.83 \\
\hline
\end{tabular}


big impact on the economic performance of the activity due to the high percentage that it represents, in most of the properties, on the total invested amount. In some cases, the land represents $70 \%$ of the invested capital, according to the 2005 Minas Gerais dairy livestock survey.

Although it is largely used and promoted as being a deciding factor in determining the activity remuneration, the daily milk production in this case did not have correlation with the remuneration rate of capital (Table 7). Both the lack of correlation of the number of lactating cows and the daily milk production with the economic business performance are perfectly understandable. One can have a high number of cows with low remuneration of capital, if the production of these animals is incompatible with the expenditures with the business. On the other hand, a low number of animals may proportionate good capital remuneration if their production is balanced with the structuring of the production costs (mainly the overhead costs). Concerning the daily production, the same previous analysis can be done. To just increase the production might not be sufficient to obtain the best capital return; there is need to match the production increase with strict control of the production costs. When operating with a negative net margin or gross margin, for example, the production increase alone would never be able to improve the rate of return on capital. On the other hand, a simple adjustment on the cost structuration may be sufficient to proportionate a better rate of return on capital with no increase in the daily milk production.

As opposed to what Oliveira et al. (2007) observed, there was no correlation $(\mathrm{P}>0.10)$ between the relation of cows in lactation per total herd and the rate of return on capital. The relation of labor cost and concentrate feed cost with milk gross revenue did not have a correlation $(\mathrm{P}>0.10)$ with economic performance (Table 7). Although labor and concentrate are the two main components of cost in the dairy livestock production, their expenses in relation to gross revenue of the dairy business did not show correlation $(\mathrm{P}>0.10)$ with rate of return on capital. This is possibly due to the fact that the other agricultural inputs that were spent in the milk production have their use adjusted to compensate the higher or lower expenses with the labor and with the concentrate. This lack of correlation $(\mathrm{P}>0.10)$ of the two agricultural inputs with the rate of return does not reduce the importance of optimizing their use, especially labor, which, in the last years, has gone through continuous real adjustments above the inflation value. According to Gomes (2008), although the labor productivity has been higher in the last years, the salary increase caused an elevation of $7.7 \%$ a year in total cost with labor in the period from 2002 to 2007 . The analyzed sample was the milk producers that participated in the Educampo project.

The milk price and the total stock of capital invested in the business also did not have correlation $(\mathrm{P}>0.10)$ with the rate of return on capital. The ratio of lactating cows per total cows of the herd (indicator known as percentage of lactating cows) showed to be highly correlated $(\mathrm{P}<0.10)$ with the rate of return on capital (Table 7). The factors lactating cow productivity, lactating cows per total cows and labor productivity had correlation $(\mathrm{P}<0.10)$ with the rate of return on capital.

Table 7 - Correlation coefficients and descriptive levels of probability ( $\mathrm{P}$ value) of indicators evaluated with the remuneration rate of invested capital (\% per year)

\begin{tabular}{lcc}
\hline Index & Correlation coefficient & P value \\
\hline Daily milk production & 0.0867 & 0.3747 \\
Area utilized for the dairy activity & -0.3764 & 0.0754 \\
Number of lactating cows & -0.1427 & -0.2551 \\
Total number of cows & 0.7286 & 0.2990 \\
Relation of lactating cows per total cows & 0.2048 & 0.1701 \\
Relation of lactating cows per total herd & 0.6728 & 0.6362 \\
Number of lactating cows per area & 0.7515 & 0.2234 \\
Milk production per lactating cow & 0.4740 & 0.0021 \\
Milk production per total cows & 0.7509 & 0.0040 \\
Labor productivity & -0.2018 & 0.0004 \\
Land productivity & -0.4719 & 0.0318 \\
Average milk price & -0.6289 & 0.0004 \\
Relation of milk effective operational cost per milk price & -0.7301 & 0.2268 \\
Relation of milk total operational cost per milk price & -0.4269 & 0.0325 \\
Relation of milk total cost per milk price & 0.2751 & 0.0045 \\
Relation cost labor per milk gross revenue & 0.7619 \\
Relation of concentrate cost per milk gross revenue & -0.4423 \\
Relation of net margin of the dairy activity per gross revenue of the activity (profitability) & -0.2115 \\
Relation of capital invested in the activity per milk produced daily & 0.0007 \\
Stock of capital invested in the activity including land & 0.0495 \\
\hline
\end{tabular}


The ratio of effective operational costs, total operational cost and total cost with the milk price had high negative correlation $(\mathrm{P}<0.10)$ with the rate of return on capital (Table 7). According to the Educampo Project data center, the effective operational cost, total operational cost and total cost per liter of milk must be respectively lower than $70 \%, 80 \%$ and $90 \%$ of the milk price. The higher these values, possibly the lower the gross margin, net margin and business profit, and consequently the lower the capital remuneration invested in the activity, which is calculated using the net margin divided by the total involved in the production.

The relation net margin per business gross revenue was highly correlated $(\mathrm{P}<0.10)$ with the profitability. This indicator (profitability) represents the business gross revenue percentage that remained after the disbursements were paid (effective operational cost) and also the depreciation and own labor or compensation.

The relation capital invested in the activity per milk produced daily also had negative correlation $(\mathrm{P}<0.10)$ with the rate of return on capital. According to Gomes (2005), this indicator is very important for the evaluation of the efficiency of milk production systems, since the higher the invested value to produce, the higher should be the net margin to obtain a good rate of return on capital.

To obtain a rate of return on capital of $12 \%$ per year, the area used for dairy livestock should be of approximately 73 ha (Tables 8 and 9). In the dairy livestock survey of Minas Gerais of 2005, the average area used on milk production by the producers was 57 ha. Those that produced 500 to 1000 liters of milk per day (category which fits the producers who formed this study sample), were using 130 ha. For the producers of the 2005 sample survey, this larger quantity of area (130 ha) was possibly crucial to the rate of return on capital, which was $3.72 \%$ a year for the category 500 to 1000 liters per day.

The percentage of lactating cows (lactating cows/ total cows) must be $82 \%$ to achieve $12 \%$ of RRC. This evidence reinforces the theory that to have an economically competitive production, a herd must have, on average,

Table 8 - Regression parameters, probability descriptive levels (P value) and determination coefficients $\left(\mathrm{r}^{2}\right)$ of the economic, animal performance and size indicators, in relation to the rate of return on invested capital (RRC, \% a year)

\begin{tabular}{|c|c|c|c|}
\hline Dependent variable & Regression parameter & P value & $\mathrm{r}^{2}$ \\
\hline Area used for the dairy activity, ha & $\mathrm{Y}=125.55-4.41 \mathrm{RRC}$ & 0.1507 & 0.1417 \\
\hline Relation of lactating cows per total cows, $\%$ & $\mathrm{Y}=67.27+1.19 \mathrm{RRC}$ & 0.0014 & 0.5308 \\
\hline Number of lactating cows per area, cows/ha & $\mathrm{Y}=0.55+0.056 \mathrm{RRC}$ & 0.0043 & 0.4527 \\
\hline Milk production per lactating cows per area, L/cow/day & $\mathrm{Y}=9.16+0.48 \mathrm{RRC}$ & 0.0081 & 0.4047 \\
\hline Milk production per total cows, L/cow/day & $\mathrm{Y}=6.07+0.52 \mathrm{RRC}$ & 0.0008 & 0.5648 \\
\hline Labor productivity, L/day labor & $\mathrm{Y}=243.05+13.21 \mathrm{RRC}$ & 0.0636 & 0.2247 \\
\hline Land productivity, L/ha/year & $\mathrm{Y}=1698.66+442.12 \mathrm{RRC}$ & 0.0008 & 0.5638 \\
\hline Relation of milk effective operational cost per milk price, $\%$ & $\mathrm{Y}=76.67-1.34 \mathrm{RRC}$ & 0.0650 & 0.2227 \\
\hline Relation of milk total operational cost per milk price, $\%$ & $\mathrm{Y}=90.89-1.86 \mathrm{RRC}$ & 0.0091 & 0.3956 \\
\hline Relation of milk total cost per milk price, $\%$ & $\mathrm{Y}=109.66-2.72 \mathrm{RRC}$ & 0.0013 & 0.5330 \\
\hline Relation of labor cost per milk gross revenue, $\%$ & $\mathrm{Y}=19.71-0.86 \mathrm{RRC}$ & 0.0991 & 0.1823 \\
\hline Relation of net margin of the dairy activity per gross revenue of the dairy activity (profitability), $\%$ & $\mathrm{Y}=1.69+2.16 \mathrm{RRC}$ & 0.0006 & 0.5804 \\
\hline Relation of capital invested in the activity per milk produced daily, R\$/L-day & $\mathrm{Y}=1199.58-46.31 \mathrm{RRC}$ & 0.0863 & 0.1956 \\
\hline
\end{tabular}

Table 9 - Benchmarks of milk producer companies participants of Educampo Project in Minas Gerais State, in four scenarios of remuneration rate of invested capital $(6,8,10$ and $12 \%$ a year)

\begin{tabular}{|c|c|c|c|c|}
\hline \multirow{2}{*}{ Benchmark } & \multicolumn{4}{|c|}{$\mathrm{RRC}^{1}$ (\% a year) } \\
\hline & 6 & 8 & 10 & 12 \\
\hline Area utilized for the dairy activity, ha & 99.09 & 90.27 & 81.45 & 72.63 \\
\hline Relation of lactating cows per total cows, $\%$ & 74.41 & 76.79 & 79.17 & 81.55 \\
\hline Relation of lactating cows per area, cows/ha & 0.89 & 0.99 & 1.11 & 1.22 \\
\hline Milk production per lactating cow, L/cow/day & 12.04 & 13.00 & 13.96 & 14.92 \\
\hline Milk production per total cows, L/cow/day & 9.19 & 10.23 & 11.27 & 12.31 \\
\hline Labor productivity, L/day labor & 322.31 & 348.73 & 375.15 & 401.57 \\
\hline Land productivity, L/ha/year & 4351.38 & 5235.62 & 6119.86 & 7004.10 \\
\hline Relation of milk effective operational cost per milk price, $\%$ & 68.63 & 65.95 & 63.27 & 60.59 \\
\hline Relation of milk total operational cost per milk price, $\%$ & 79.73 & 76.01 & 72.29 & 68.57 \\
\hline Relation of milk total cost per milk price, $\%$ & 93.34 & 87.90 & 82.46 & 77.02 \\
\hline Relation of labor cost per milk gross revenue, $\%$ & 14.55 & 12.83 & 11.11 & 9.39 \\
\hline Relation of net margin of the dairy activity per gross revenue of the dairy activity (profitability), $\%$ & 14.65 & 18.97 & 23.29 & 27.61 \\
\hline Relation of capital invested in the activity per milk produced daily, R\$/L-day & 921.72 & 829.10 & 736.48 & 643.86 \\
\hline
\end{tabular}

${ }^{1}$ RRC - Remuneration rate of invested capital including land price. 
throughout the year, at least $83 \%$ of the cows under production and only $17 \%$ dry. On the 2005 survey, the average found was $66 \%$ of cows in lactation in relation to the total cows. The value found for Minas Gerais in 2005 would not be sufficient even to proportionate $6 \%$ of RRC. The value herein found to proportionate $6 \%$ a year was $74 \%$ of cows in lactation.

Regarding the stocking indicator, 1.22 cows in lactation per ha were necessary to achieve $12 \%$ remuneration rate of capital. With 0.89 cows in lactation per ha, in this study, the annual remuneration rate of capital invested in the activity obtained was $6 \%$. For the Educampo Project data center, this indicator should be of at least one cow in lactation for each ha destined to the dairy livestock, to proportionate a good economic performance.

In this study, the observation by Oliveira et al. (2007), that the animal productivity is of major importance in the remuneration rate of capital was confirmed. To achieve 6 , 8,10 and $12 \%$ of $\mathrm{RRC}$, the milk production in lactation necessary was respectively $12,13,14$ and $15 \mathrm{~L} /$ cow/day. Increase in productivity per cow with balanced costs results in better remuneration to capital.

To achieve $12 \%$ in the remuneration rate of capital, the labor productivity was $402 \mathrm{~L} / \mathrm{man} /$ day. This value is high, if considering the milking done manually. Thus, there is a need for milking mechanization as an important tool to increase the labor productivity and consequently improve the economic result of the activity. In this case, $81 \%$ of the properties use mechanized milking. In the survey of Minas Gerais of 2005, the average of 182 liters of milk per day/man was found among the producers (with $17 \%$ of the farms using milking machine). This average is far behind 322 daily liters per man, necessary to obtain $6 \%$ of RRC among the producers of the region of Ituiutaba-MG. The value found in this study shows the need to intensify the production per day/man, to be well succeeded in the dairy livestock activity in the region of Triângulo Mineiro. This is possibly due to the fact that the labor cost in this region is relatively high due to the several job offers available mainly from the sugar cane mills. In the same survey of Minas Gerais of 2005, the producers of 500 to $1000 \mathrm{~L}$ of milk/day presented a production of $297 \mathrm{~L} / \mathrm{man}$ a day. Not coincidentally, the RRC of this group, which was part of the 2005 survey, was $3.72 \%$ a year.

The main indicator that measures the use of land efficiency, is the milk production per ha a year. In this study, to achieve 6 and $12 \%$ of remuneration rate of capital a year, the values 4,351 and 7,004 L/ha/year were respectively found. In the dairy livestock survey of Minas Gerais of 2005, the values found for the state average and for the group of 500 to 1000 liters/day were respectively 1,188 and $1,955 \mathrm{~L} / \mathrm{ha} /$ year. The state average is far behind the 4,531 liters per ha per year needed to obtain $6 \%$ of RRC among the producers of Ituiutaba-MG, in Triângulo Mineiro. The hectare price of bare land of approximately $\mathrm{R} \$ 6,000.00$ in the region of Ituiutaba-MG has direct influence in the need to produce high quantity of milk per area aiming at a good invested capital remuneration rate.

Values of 61, 69 and 77\% were found respectively for the relation effective operational cost, total operational cost and milk total cost with the milk price, to achieve $12 \%$ of RRC. According to the Educampo data center, the production systems of higher efficiency presented values close to 65,75 and $85 \%$ for the three respective levels of milk price cost. For the study in question, these values should be slightly lower than those recommended by the Educampo data center.

One of the inputs of big impact on milk production in most of the systems is labor. In this case, the value of milk gross revenue spent with hired labor reached $9 \%$, to obtain $12 \%$ on remunerate rate of capital invested in the activity. According to the Educampo data center, the value spent with labor by the higher-efficiency farms is of about $15 \%$ of milk gross revenue. Once again, the region of Triângulo Mineiro differs a little from the general recommendation of the data center. In this case, only $9 \%$ of the milk gross revenue can be spent with labor to obtain capital remuneration rate of $12 \%$ a year. Spending $15 \%$ of the milk gross income to pay the hired labor, in the case of producers sampled in the region of Ituiutaba-MG, would be sufficient for a remuneration rate of capital of only $6 \%$ a year.

To achieve $12 \%$ on RRC, the farms of these groups can have invested capital in the value of $R \$ 645.00$ per liter of milk produced a day. This value is much lower than that found in the dairy livestock survey of Minas Gerais in 2005 , which was $\mathrm{R} \$ 2,440.00$ per liter of milk produced a day. With this high invested value to produce one liter of milk daily, the remuneration rate of capital would be high for the producers sampled by the 2005 survey. With this high invested value to produce a liter of milk daily, the remuneration rate of capital would hardly be high to the producers sampled in the survey of 2005. Confirming the expectation of low economic performance, in the survey, the RRC was $1.92 \%$ a year in the average of the state. According to the Educampo Project data center, the invested capital value to produce a liter of milk daily in companies of good economic performance is lower than $\mathrm{R} \$ 500.00$. For the data center, values above this compromise the remuneration rate of capital performance. In this study, the values surpassed $\mathrm{R} \$ 500.00$, but with remuneration rates of capital relatively attractive in the financial market. Even the R\$922.00 
invested per liter of milk produced daily still proportionate a RRC of $6 \%$ a year. These differences between the values reached and the literature quotes reinforce the arguments of Oliveira et al. (2007) about the necessity of these indicators to be analyzed in a regionalized way in order to eliminate the effects caused by socio cultural and even economic and climate particularities, in which the systems are inserted.

\section{Conclusions}

The productivity of the factors land and animal present higher correlation with profitability than the factors associated with labor productivity, regardless of the production size, in dairy cattle production systems. Benchmarks obtained for the Minas Gerais state differ from global rates, which indicates the necessity for regionalized studies.

\section{References}

DIAGNÓSTICO da pecuária leiteira do estado de Minas Gerais: Relatório de pesquisa. (2005). Belo Horizonte: SEBRAE-MG/ FAEMG, 2006. 156p.

FASSIO, L.H.; REIS, R.R.; GERALDO, L.G. Technical and economical effectiveness of milk production from Minas Gerais state, Brazil. Ciência e Agrotecnologia, v.30, p.1154-1161, 2006.

FERGUSON, C.E. Microeconomia. 19.ed. Rio de Janeiro: Florence Universitária, 1996. 610p.

FGVDADOS. Informações econômicas online. Available at: $<$ http://www.fgvdados.com.br> Accessed on: Dec. 1, 2011.
GOMES, S.T. Mão-de-obra é a bola da vez. Jornal da Produção de Leite. Convênio DPA/FUNARBE/UFV, ano XVIII, n.227, janeiro 2008.

GOMES, S.T. Benchmark da produção de leite em MG. Available at: $<$ http://www.milkpoint.com.br/mn/espacoaberto/artigo.asp?nv= $1 \&$ id_artigo $=23393 \&$ area $=23 \&$ perM $=12 \&$ perA $=2005>$ Accessed on: Dec. 1, 2005.

INSTITUTO BRASILEIRO DE GEOGRAFIA E ESTATÍSTICA IBGE. Banco de dados. Available at: $<$ http://www.sidra.ibge.gov. $\mathrm{br} / \mathrm{bda} /$ tabela/listabl.asp? $=74 \& \mathrm{z}=\mathrm{t} \& \mathrm{o}=20>$ Accessed on: Dec. 10 , 2005.

KRUG, E.E.B. Estudo para identificação de benchmarking em sistemas de produção de leite no Rio Grande do Sul. 2001. 191f. Dissertação (Mestrado em Administração para Executivos) Universidade Federal do Rio Grande do Sul, Porto Alegre.

MAGALHÃES, A.L.R.; CAMPOS, J.M.S.; VALADARES FILHO, S.C. et al. Efeito da substituição da silagem de milho pela cana-deaçúcar sobre a produção e metabolismo ruminal de vacas leiteiras em lactação. Revista Brasileira de Zootecnia, v.35, p.591-599, 2006.

OLIVEIRA, A.S.; CUNHA, D.N.; CAMPOS, J.M.S. et al. Identificação e quantificação de indicadores referencia de sistemas de produção de leite. Revista Brasileira de Zootecnia, v.36, p.507-516, 2007.

OLIVEIRA, A.S.; PEREIRA, D.H. Gestão econômica de sistemas de produção de bovinos leiteiros. In: SIMPÓSIO BRASILEIRO DE AGROPECUÁRIA SUSTENTÁVEL, 1., 2009, Viçosa, MG. Anais... Viçosa, MG, 2009. p.106-133.

RUAS, J.R.M.; BRANDÃO, F.Z.; BORGES, L.E. et al. Influência da presença do bezerro no momento da ordenha sobre o desempenho reprodutivo de vacas mestiças Holandês-Zebu. Arquivo Brasileiro de Medicina Veterinária e Zootecnia, v.59, p.218-224, 2006.

SILVA, H.A.; KOEHLER, H.S.; MORAES, A. et al. Análise da viabilidade econômica da produção de leite a pasto e com suplementos na região dos Campos Gerais - Paraná. Ciência Rural, v.38, n.2, p.445-450, 2008. 